\title{
RETHINKING MAIURI: ENHANCEMENT OF STUCCO FINDINGS FROM THE HERCULANEUM ARCHAEOLOGICAL PARK
}

\section{CAPASSO Filippo Edoardo, CASTIELLO Francesca, DICHIARA Simona, GIANDOMENICO Manuel, IACOPINO Natalie, MADDALENA Erika, MAURI Camilla, MUCA Sokol, ROSCIGNO Mariagiulia, SCHIATTONE Sofia ${ }^{1}$}

1 Students at the ISCR, Higher School of Conservation and Restoration of the Cultural Heritage in Matera. The Supervisors are Antonio Guglielmi and Angelo Raffaele Rubino of the ISCR, Corinna Ranzi and Chiara Scioscia Santoro, contractors for ISCR, and the Chief Supervisor is Giorgio Sobrà, Architect, Director of the Higher School of Conservation and Restoration of the Cultural Heritage of ISCR, in Matera

CAPASSO: https://orcid.org/0000-0001-7258-1703; CASTIELLO: https://orcid.org/0000-0002-6075-5224

DICHIARA: https://orcid.org/0000-0001-4375-2742 ; GIANDOMENICO: https://orcid.org/0000-0001-6994-0453

IACOPINO: https://orcid.org/0000-0001-6531-6426 ; MADDALENA: https://orcid.org/0000-0002-0507-2121

MAURI: https://orcid.org/0000-0001-6415-3426 ; MUCA: https://orcid.org/0000-0002-6715-5969

ROSCIGNO: https://orcid.org/0000-0001-8047-5222 ; SCHIATTONE: https://orcid.org/0000-0002-9026-344X

ABSTRACT: The subject of this study is a group of ninety stucco fragments from the Herculaneum Archeological Park, which were part of the decoration of the Tetrapylon's barrel vault located in the Decumanus Maximus. The archaeologist Amedeo Maiuri, former superintendent of the site, had been displaying them in a cabinet within a nearby domus, as part of his project of an open air museum, while other parts of the stucco decoration were repositioned in situ, with large lacunas. Our project's aim has been to develop a new exhibition solution, pursuing an accurate recovery of the overall volume of the decoration, meeting the requirements of reversibility and stability of conservation-restoration treatments, while allowing further updates through new findings. Considering the wide range of methods at our disposal, the most effective technical support in matching the fragments, and acquiring accurately the shape has shown to be the 3D scanning and modeling.

KEYWORDS:Stucco fragments, Hercolaneum, Roman architecture, Amedeo Maiuri, 3D acquisition, reconstruction proposal, integration

During the academic year 2017-2018 ninety stucco fragments from the Herculaneum Archeological Park became the subject of conservations treatments within the ISCR laboratories in Matera, in the frame of the didactic activities of the School for Superior Training and Study in Conservation and 
Restoration of the Cultural Heritage of ISCR.

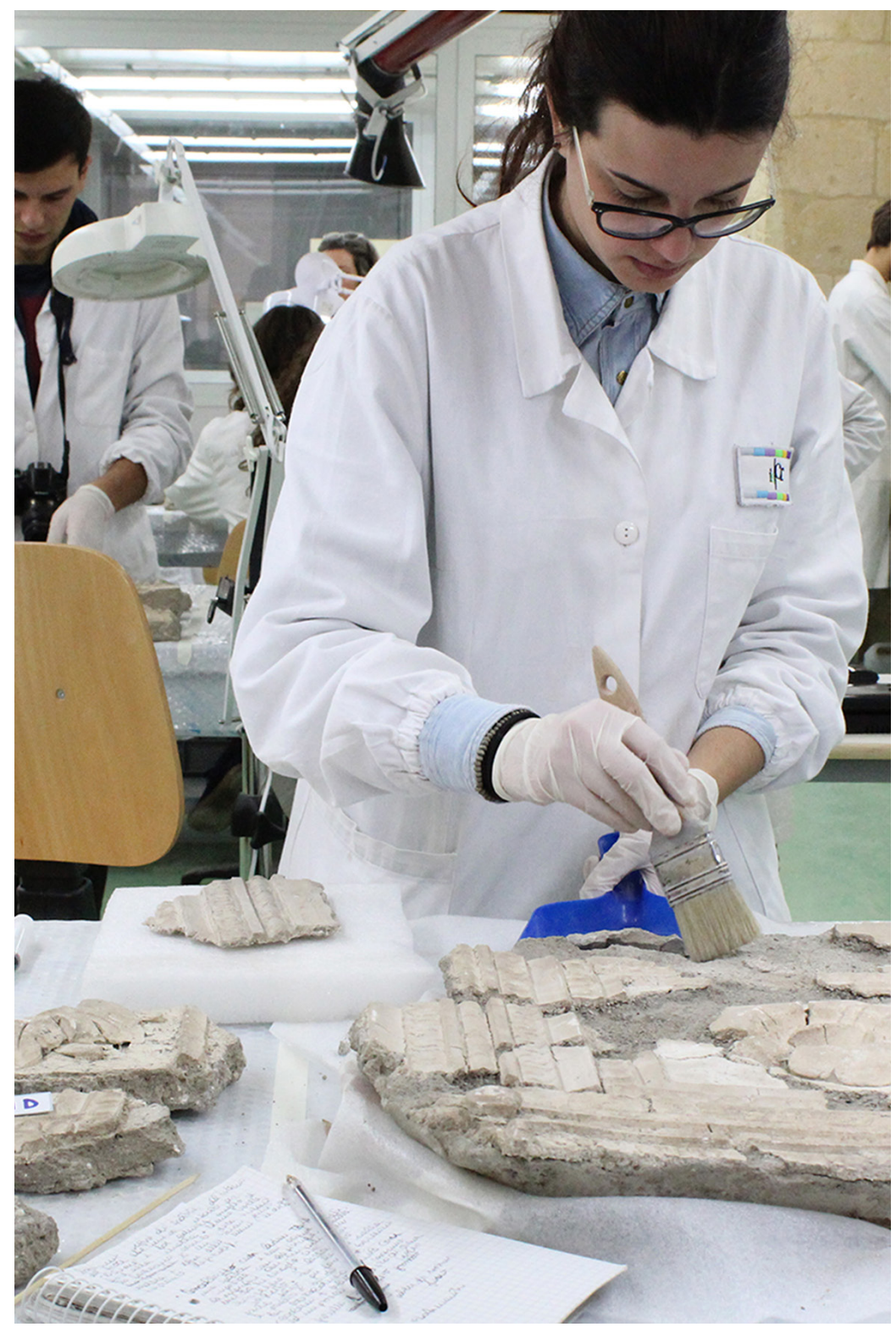

Fig. 1 Students working on the stucco fragments in the ISCR laboratories in Matera. (Photo Credit: ISCR-Matera students)

The artifacts were found in the 20th century excavation, inside the volcanic sediment, and were identified as part of the decoration of the Tetrapylon (end of the 1st century B.C. - beginning of the 1st century A.D. $)^{1}$ located in the Decumanus Maximus. Some parts of the stucco decoration were found

1 Dating can be deduced from the pre-existing Augusteum, which, according to Mario Pagano (Pagano 1996, p. 229 ff.), and Mario Torelli (Torelli 2004, p. 117-149), was built between I cent. B.C. - I cent. A.D. 
still in place, while the collapsed ones, following a general museographic project for the site planned in the mid-20th century by the archaeologist and superintendent Amedeo Maiuri², were repositioned on the barrel vault's inner surface.

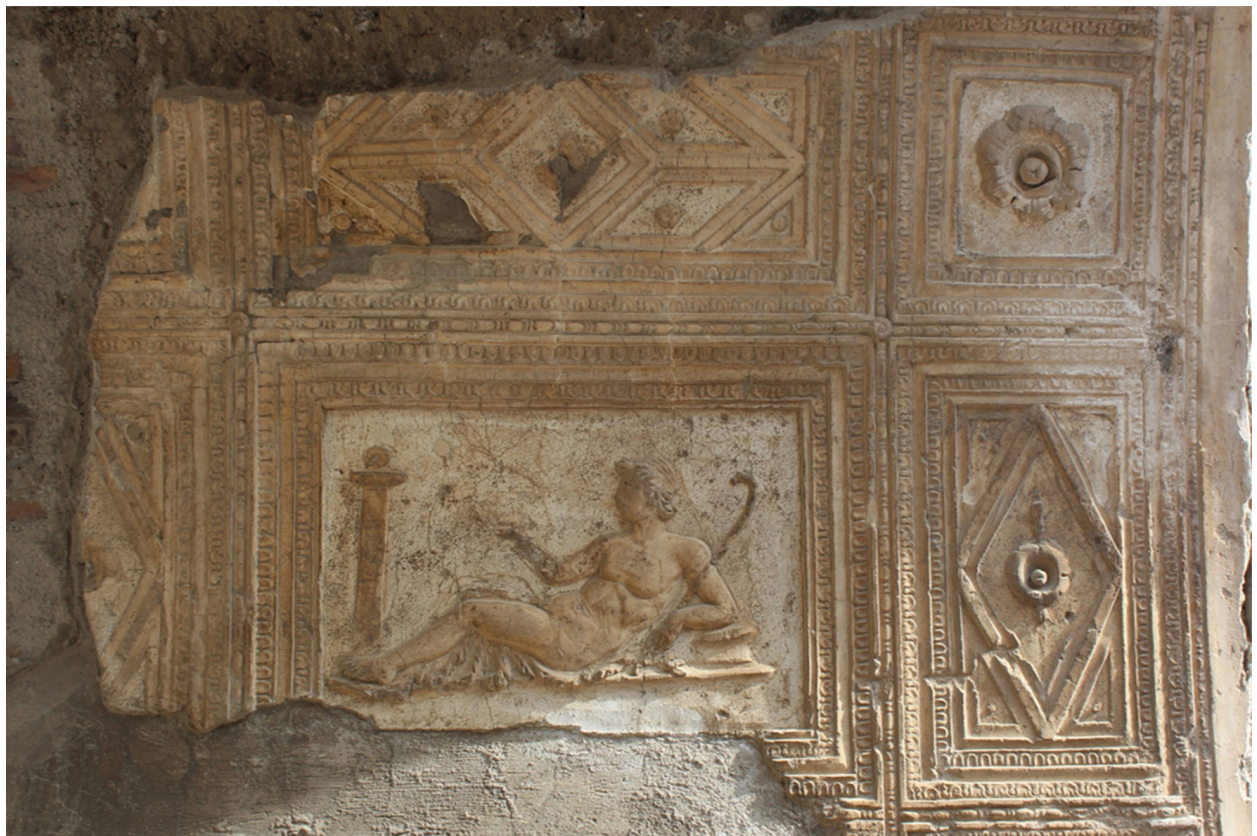

Fig. 2 Stucco decoration in situ, Tetrapylon, Herculaneum. (Photo Credit: ISCR-Matera students)

The subjects of this study, although being significant findings, could not be placed back within the arch, so they were displayed in a cabinet, intended as part of Maiuri's open air museum. Such showcase would have required a regular maintenance if located inside a museum; putting it in an outdoor environment revealed to be instead a very demanding choice: the fragments within it were not, in fact, protected against the agents of degradation, in particular dust deposits, biological colonisation and water condensation inside the glass cabinet.

On the other hand, this showcase filled with a mass of overlapping fragments, wasn't an effective instrument to properly enhance the artifacts' aesthetic value. Its position inside the emporium VI,16 (see: Camardo \& Notomista, 2017, p. 250), facing the founding area but not visually or functionally connected with it, was of no help for the comprehension of fragments' provenance form the Tetrapylon. As a result of these circumstances, and after sixty years circa from this first exposition solution, the option of putting the fragments back in their old showcase appeared to be no more suitable for their conservation. The conservation-restoration activity on the fragments was then flanked by a new design process, aimed at giving back the potential integrity of the work of art, by rethinking the solutions elaborated under Maiuri.

\footnotetext{
2 Maiuri was the chief archaeologist and director of Pompeii Archaeological Park from 1924 to 1961. Since 1927 he undertook the Herculaneum project, leaving the eighteenth-century tunnel investigations methodology in favour of wider excavations bringing to light the city. To have a clearer insight on Maiuri's activity in the Vesuvian cities the recent publication on Ercolano 1927 - 1961 can be consulted (see: Camardo \& Notomista, 2017).
} 
Anyway, the limited number of fragments cannot be placed in their context within the building because of two reasons. The first one is the lack of reliable data regarding the lacunaria decoration, having different geometries as square, rectangular or diamond shaped, and including both figurative representations moulded in relief and a variety of ornaments, ranging from zoomorphic to phytomorphic and human-like motifs. The second one is the impossibility to reintegrate with these very few elements the large missing portion of the Tetrapylon vault. What is more, there is the further chance to increase the number of excavation fragments belonging to the arch, searching the archaeological park storerooms.

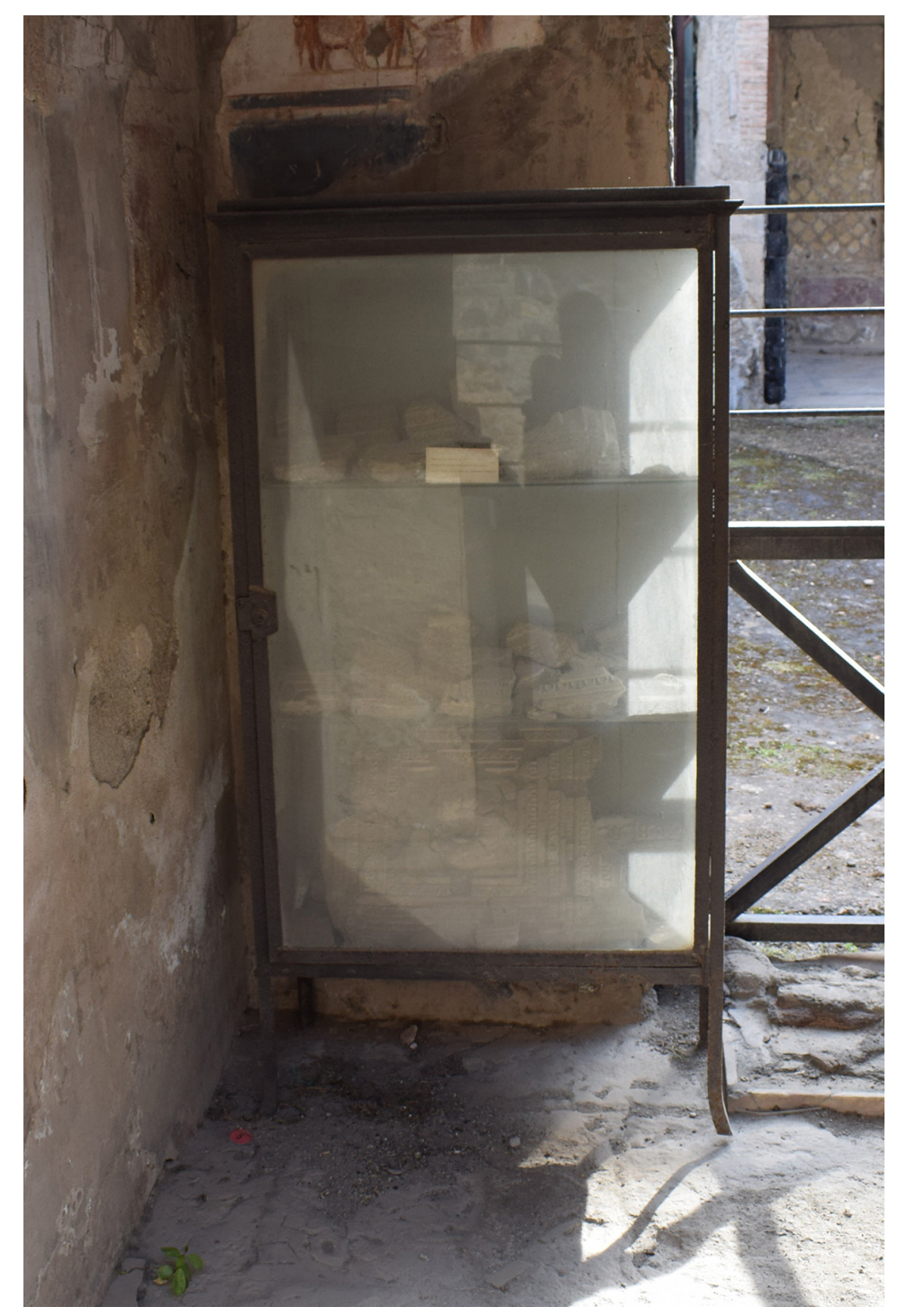

Fig. 3 Stucco fragments inside the display cabinet in situ, before the conservation treatments. (Photo Credit: ISCR-Matera students) 
The methodological approach to this problem has revealed to be closer to the one used during the in situ replacement of the fragments from the barreled vault of the Tetrapylon, only differing in the use of technologies and materials nowadays available, which allow a better compatibility with the constitutive material.

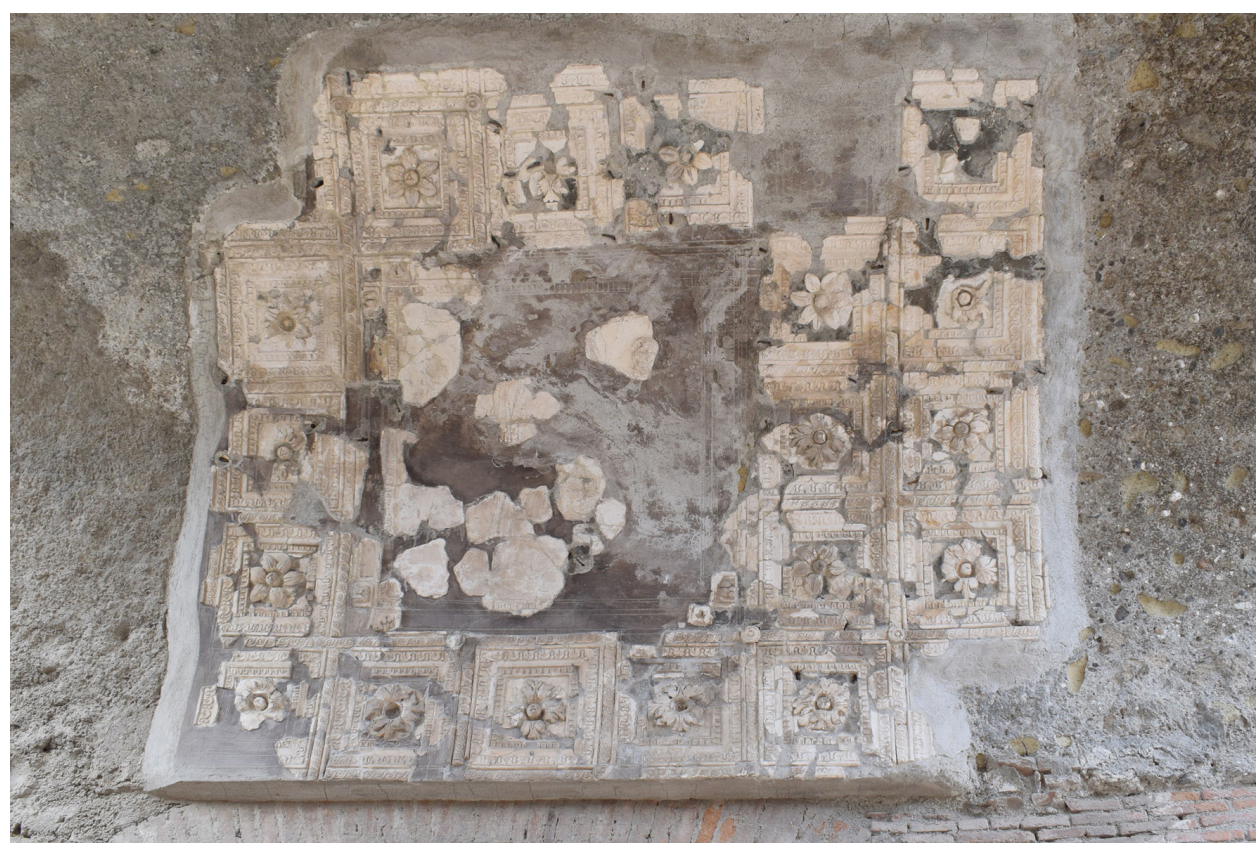

Fig. 4 Stucco Fragments repositioned on the barrel vault's inner surface on Maiuri's project. (Photo Credit: ISCR-Matera students)

Hence, the intervention is based on the theoretical and technical evolution of conservation and the techniques of the $21^{\text {st }}$ century, the goal being the restitution of the overall volume of the decoration, by simplified integrations, suggesting the various ornament modules, and enhancing the stucco fragments through a more appropriate exhibition system and with a more correct reading key, while respecting the previous historicized intervention.

The solution was then to obtain a free-standing structure, suitable to collect and display the different stucco findings currently available, but not excluding the revision of the exhibition system for a wider number of fragments, according to the different display conditions existing in a museum environment or in situ. Therefore, the intervention should have been reversible and constantly updatable. Besides, considering Herculaneum seismicity, the exhibition system should meet certain requirements, like stability and self-supporting structure. 

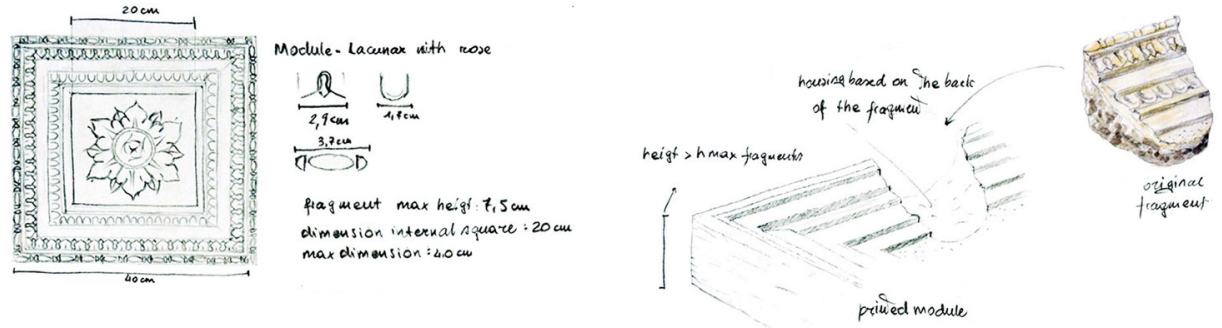

Fig. 5 Sketch of the restitution of the overall volume of the decoration in the exhibition. (Author of the sketch: ISCR-Matera students)

The first problem in trying to design this new exhibit was then to understand the ancient position of the fragments within the building, since the Roman stucco technique generally consisted in the repetition of modular decoration. This practice permitted in antiquity to solve quickly and accurately the modeling of the architectonic surfaces, while other figures could be directly modeled in the lime mortar ${ }^{3}$. But the molds employed for the decoration could have different dimension and shapes, imprinting small differences in the decorative pattern. These differences have revealed very useful to understand the right position of each fragment and the general appearance or the vault's lacunaria decoration. On the basis of these information it was thus possible to propose the reconstruction and the re-collocation of the stucco fragments in situ.

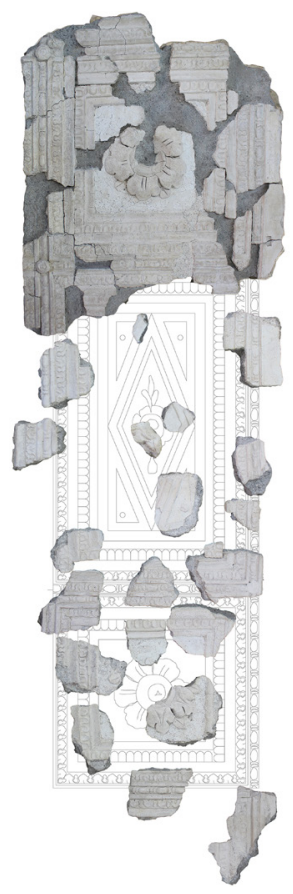

Fig. 6 Graphic reconstruction of the decoration and repositioning of the stucco findings. (Author of the graphic reconstruction: ISCR-Matera students)

3 The most acknowledged publication on Roman building technique, that our team referred to for the stucco decoration study, is Adam, 2005. 
Since there are no matchings, the guide line for juxtaposing the artefacts is the state of conservation and the graphic reconstruction of the decorative features. This approach was already used soon after the excavations, when the first attempt of matching fragments, with no archaeological clues of the right original position, took place: some of the stuccos were hence placed according to a philological method. As a result, fragments were placed side by side without having a real contact between them.

In the preliminary phases of the intervention here exposed, in addition to shape, dimension and decorative features, the stucco fragments were also analyzed with a special attention to the traces of molds orientation and to their conservation conditions. In fact, most of the deterioration process occurred before the destruction of the monument and the fragments were then sealed up for centuries, so similar conservation conditions represent a hint for a nearby ancient position of the fragments. For this reason, stucco elements with a highest level of erosion were distinguished by those in a good conservation state. At the same time, fragments featuring different ornaments orientation from the ones belonging to the main decoration were put aside, because they couldn't match with them.

The second main issue was the identification of the most suitable integration techniques. In the last decades the most employed system for the assembling of fragmentary ancient wall decorations (such as mural paintings, mosaics and stuccos) consisted in the fragments' lodging by means of a mortar that reproduces the preparatory layer, thus obtaining a sublevel. ${ }^{4}$. This mortar can also have the purpose to suggest the missing part of the decorations, reproducing the general design through its direct incision on the surface. This method is still commonly applied in archaeological sites or in museum exhibition, thus it can be considered as one of the most tested systems. The disadvantages of that solution are nevertheless various: it is not easily updatable and it doesn't entirely develop the overall volumes of the original decoration.

Another solution taken into account does not imply any plaster to assemble the fragments and to reproduce the preparatory layers. It consists instead in gathering the fragments of the decoration on a panel that reproduce the arching of the vault. In this solution the design of the decoration can be simply recalled by means of a digital print $t^{6}$, directly applied on the panel. If compared to the first one, this proposal allows the insertion of further stucco fragments that could be discovered in additional researches. Besides, the main matter of using a digital print is that it doesn't allow the perception of the three-dimensional volume of the original.

$4 \quad$ This method is exemplified by the intervention conduced upon the stucco fragments of Villa Farnesina, now exposed in Palazzo Massimo Museum, in Rome (Gasparri \& Paris 2013, p. 399 - 400, p. 403 and p. 414 - 415).

As a matter of fact, since 1932 the Italian Carta del Restauro refers to this kind of reintegration as a proper technique for fragments dispaly: "Nelle aggiunte che si dimostrassero necessarie, o per ottenere il consolidamento, o per raggiungere lo scopo per una reintegrazione totale o parziale, o per la pratica utilizzazione del documento, il criterio essenziale da eseguirsi debba essere, oltre a quello di limitare tali elementi nuovi al minimo possibile, anche quello di dare ad essi un carattere di nuda semplicità e di rispondenza allo schema costruttivo; e che solo possa ammettersi in stile similare la continuazione di linee esistenti nei casi in cui si tratta di espressioni geometriche prive di individualità decorativa", in Carta Italiana del Restauro (1932, p.2).

A similar technique was adopted in the valorization of the image of Mantegna's mural paintings in the Cappella Ovetari in Padua (De Nicolò Salmazo, Spiazzi \& Toniolo 2006, p. 295-297), though in this case the reconstruction foresaw the application of the fragments with a mortar, while in our proposal we kept in account the mobility of the fragments, implying a different and updatable kind of anchorage system. 
In order to obtain an accurate recovery of the integrity, the most effective technical supports appear to be the 3D scanning and modeling. These methods evolved significantly in the last few years and Cultural Heritage has been a major assessment and application field ${ }^{7}$. There are several advantages in employing 3D scanning and modelling techniques: first of all, it is a contactless methodology which cannot cause any stress to the artifacts; moreover, it allows a quick volume data acquisition with a high definition of the object surface; the processing of the information can be developed through a wide range of dedicated software of modeling. Such programs allow a digital manipulation of the 3D model, adaptable to the various aims of the elaboration and to the different kind of artefacts acquired 8 .

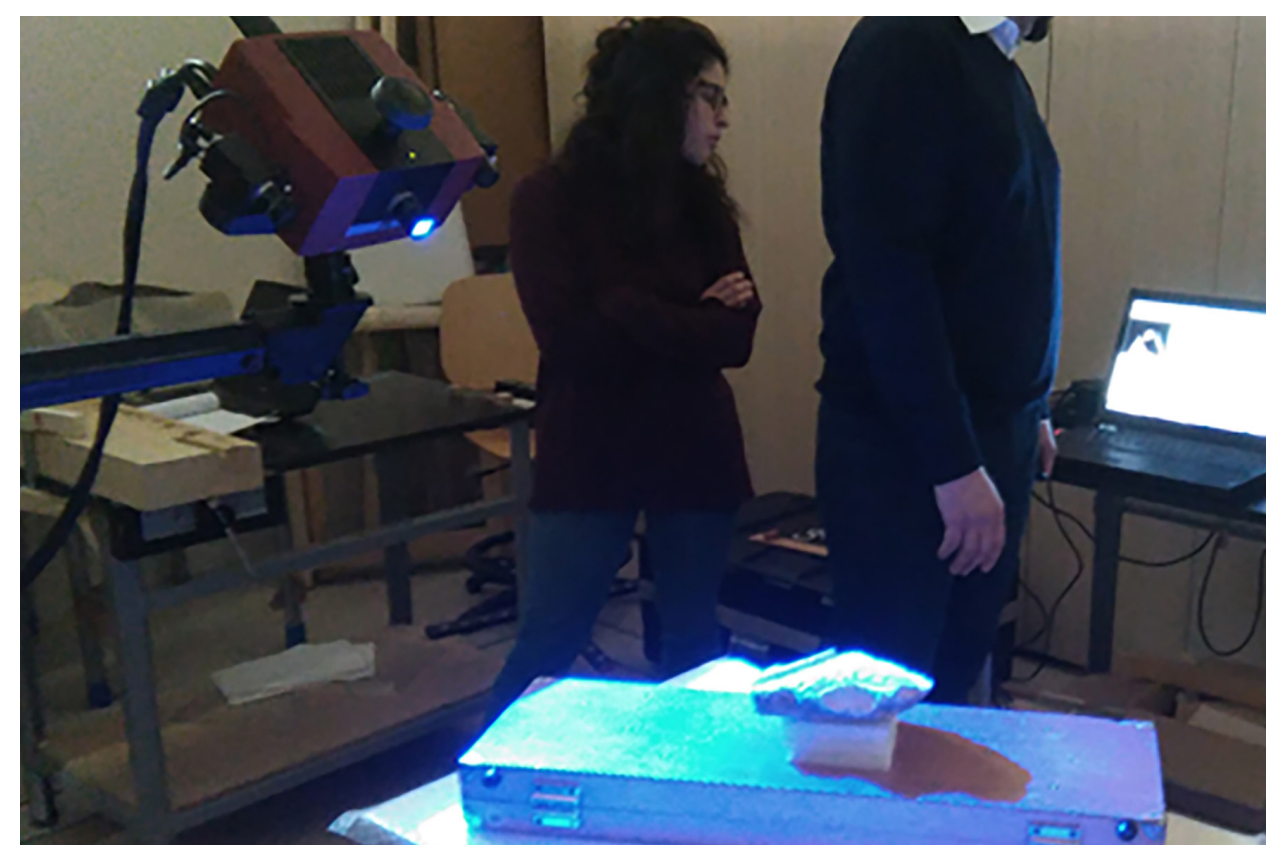

Fig. 7: Structured light scanning of a fragment of stucco. (Photo Credit: ISCR-Matera students)

In this case choosing 3D technology can firstly help in matching the fragments, by comparing the modules and design of the stuccos, with more accuracy in respect of the simple visual observation. Secondly 3D models can be compared metrically by a dedicate software, that can simplify the conservator's work of fragment's matching and alignment. The accurate metrical and visual acquisition of the stucco fragments and of the Tetrapylon architectural structure could allow eventually the unitary reconstruction of the whole decoration of the vault. The different digital models suggested will be compared, and the most effective solution will be chosen by the Direction of the Archaeological site. In fact, digital models are a clear and immediate way to show the different ideas of exhibition

In order to have an overview on the multiple options that 3D technologies offer when applied to museums exhibitions please refer to Neely, Liz; Langer, Miriam (Neely \& Langer 2013).

8 An interesting study about the application of 3D scanning and modelling, conduced in one of the vesuvian cities, is Balzani, Marcello, et al. (Balzani 2004, pp. 1-11). 
systems, allowing a $360^{\circ}$ visual of the structure, that can be spent at diverse stages of the project: during the conservation process, as a tool for the documentation; in the monitoring of the operations; as mathematical model for the designing of the external support for the fragments decoration ${ }^{9}$, and for the study of its statics.

Once chosen this kind of solution, the third problem to solve was the identification of the correct material for the 3D modelling. Nowadays there is quite a limited choice of materials that can be employed in printing 3D shapes on the basis of a digital model ${ }^{10}$. A product suitable for reintegration should fulfill several properties, such as compatibility, stability, reversibility; this cuts off the options at our disposal. Considering the possible positioning of the structure in an open air environment, there is a further restriction in the range of materials, since it would need to be stable to UV exposure and to weathering. This means that a weighted selection is compulsory, supported by scientific research concerning both the behavior of the product and its physical and chemical characterization. The choice of this material is still under debate within in the ISCR's laboratories ${ }^{11}$, pursuing specific studies aimed at understanding the features and employment restraints of the most used materials for 3D printing. In conclusion, the progress of technologies gives the chance to think of new solutions to existing problems, changing the conservator's perspective. In the field of Cultural Heritage, anyway, new technologies can be only used if the theoretical assumptions make the operation on the artefact ethically and methodologically correct ${ }^{12}$. Knowing the complexity of environment like the one of the Herculaneum Archaeological Park, where innumerable conservation-restoration activities have taken place throughout the decades, it is compelling to take in account the ideologies and cultural orientation that guided those previous interventions. It is even more important in this case, where the proposed solution is forced to face those put in place by a scholar of the stature of Amedeo Maiuri. This proposal is hence intended to follow his path, rethinking solutions supported by the $21^{\text {st }}$ century technologies.

\footnotetext{
In order to recreate the curvature of the vault measurements of the existing Tetrapylon are requested. A topographic survey of the structure and its 3D photomodel have already been realized by the Orientale University in Napoli (http://www. unior.it/ateneo/11518/basilica-di-ercolano-video.html and http://vast-lab.org/3dicons/page.php?obj=541).

10 On the other hand, the offer of materials is getting wider, but still the issue on their compatibility remains, see Neely, Liz \& Langer, Miriam op. cit. chapter "The (near) future" (Neely \& Langer 2013).

11 The most recent study led by ISCR about the 3D printing concerns the conservation of Palmiras busts. It has involved the modeling of the reintegration and its printing; for the restoration report see:

http://www.icr.beniculturali.it/documenti/allegati/RELAZIONE\%20SUL\%20RESTAURO\%20DEI\%20BUSTI\%20DA\%20 PALMIRA.pdf.

12 The ethics at the basis of our intervention and our formation arise from Brandis Theory of Restoration (Brandi 2005), especially as regards the conception of integration and its boundaries, and concerning the aesthetic presentation of the work of art.
} 


\section{Bibliography}

Adam, J.-P. (Ed.) (2005) Wall covering. In: Roman Building: Materials and Techniques (pp. 458-465). London and New York: Routledge - Taylor \& Francis.

Balzani, M. et al. (2004). Digital representation and multimodal presentation of archeological graffiti at Pompeii. In: VAST04 (Eds. Cain K., Chrysanthou Y., Niccolucci F., Silberman N.) The 5th International Symposium on Virtual Reality, Archaeology and Cultural Heritage (pp. 1-11). Aire-la Ville: The Eurographics Association.

Brandi, C. (1963). Teoria del restauro: lezioni raccolte da L. Vlad. Borrelli, J. Raspi Serra, G. Urbani ... Con una bibliografia generale dellautore. Roma: Edizioni di Storia e letteratura.

Brandi, C. (1977). Teoria del restauro. Torino: Giulio Einaudi Editore - Piccola Biblioteca Einaudi Ns. Brandi, C. (2005). Theory of Restoration. Edited by Giuseppe Basile and the Istituto Centrale per il Restauro, translated by Cynthia Rockwell. With presentations by Giuliano Urbani, Nicholas StanleyPrice, Caterina Bon Valsassina, with texts by Giuseppe Basile, Paul Philippot, Giulio Carlo Argan, Cesare Brandi. Firenze: Nardini Editore.

Camardo, D. \& Notomista, M. (2017). Ercolano 1927 - 1961: Limpresa archeologica di Amedeo Maiuri e l'esperimento della città museo. Roma: L'Erma Bretschneider

Camardo, D. \& Esposito, D. (2013). La Basilica Noniana di Ercolano. In: (Eds. von Hesberg H., Freyberger K. S.) Mitteilungen des, Romische Abteilung, vol. 119 (pp. 221-258), Rome: Deutschen Archaologischen Instituts.

Colalucci, G. \& Giantomassi, C. (2006). I lavori di ricostruzione degli affreschi della cappella Ovetari. In: (Eds. De Nicolò Salmazo A., Spiazzi A. M. \& Toniolo D.) Andrea Mantegna e i Maestri della Cappella degli Ovetari (pp. 151 -153 and p. 295-297). Milano: Skira.

Consiglio Superiore per le Antichità e le Belle Arti presso il Ministero della Pubblica Istruzione (1932) Carta Italiana del Restauro. Roma.

Gasparri, C. \& Paris, R. (Eds.) (2013) 286. Villa della Farnesina: stucchi del cubiculo B; 288. Villa della Farnesina: stucchi del cubiculo D; 297. Villa della Farnesina: stucchi del cubiculo E. In: Palazzo Massimo alle Terme: le collezioni, (pp. 399-400; pp. 403; pp. 414-415). Milano: Electa.

Neely, L. \& Langer, M. (2013) Please Feel the Museum: The Emergence of 3D Printing and Scanning. In: (Eds. N. Proctor \& R. Cherry) Museums and the Web 2013. Silver Spring (MD): Museums and the Web.

(online article, consulted in June 2018: https://mw2013.museumsandtheweb.com/paper/please-feelthe-museum-the-emergence-of-3d-printing-and-scanning/).

Pagano, M. (1996) La nuova pianta della città e di alcuni edifici pubblici di Ercolano. In: (Eds. Macchiaroli G.), Cronache Ercolanesi n²6, (pp. 229 ff.). Napoli: CISPE Marcello Gigante.

Pesando, F. \& Guidobaldi, M. P. (2006) Pompei Oplontis, Ercolano, Stabiae. Bari: Laterza.

Russo, M., Remondino, F; Guidi, G. (2011) Principali tecniche e strumenti per il rilievo tridimensionale in ambito archeologico. In: (Eds. Moscati P.) Archeologia e calcolatori n²2, (pp.169-198). Firenze: All'Insegna del Giglio. 
Stanco, F., Battiato, S. \& Gallo, G (2011) Digital Imaging for Cultural Heritage Preservation: Analysis, Restoration and Reconstruction of Ancient Artworks. New York: Taylor \& Francis Group.

Torelli, M. (2004) La Basilica di Ercolano. Una proposta di lettura. In: (Eds. Baggio M., Colpo I., Salvo G.) Eidola $n^{\circ} 1$, (pp. 117-149). Pisa-Roma: Fabrizio Serra Editore.

\section{Sitography}

http://vast-lab.org/3dicons/page.php?obj=541 (consulted in May 2018).

http://www.icr.beniculturali.it/documenti/allegati/RELAZIONE\%20SUL\%20RESTAURO\%20 DEI\%20BUSTI\%20DA\%20PALMIRA.pdf.

http://www.treccani.it/enciclopedia/stucco_\%28Enciclopedia-dell\%27-Arte-Antica\%29/.

http://www.unior.it/ateneo/11518/basilica-di-ercolano-video.html (consulted in May 2018). 
